Provided for non-commercial research and education use. Not for reproduction, distribution or commercial use.

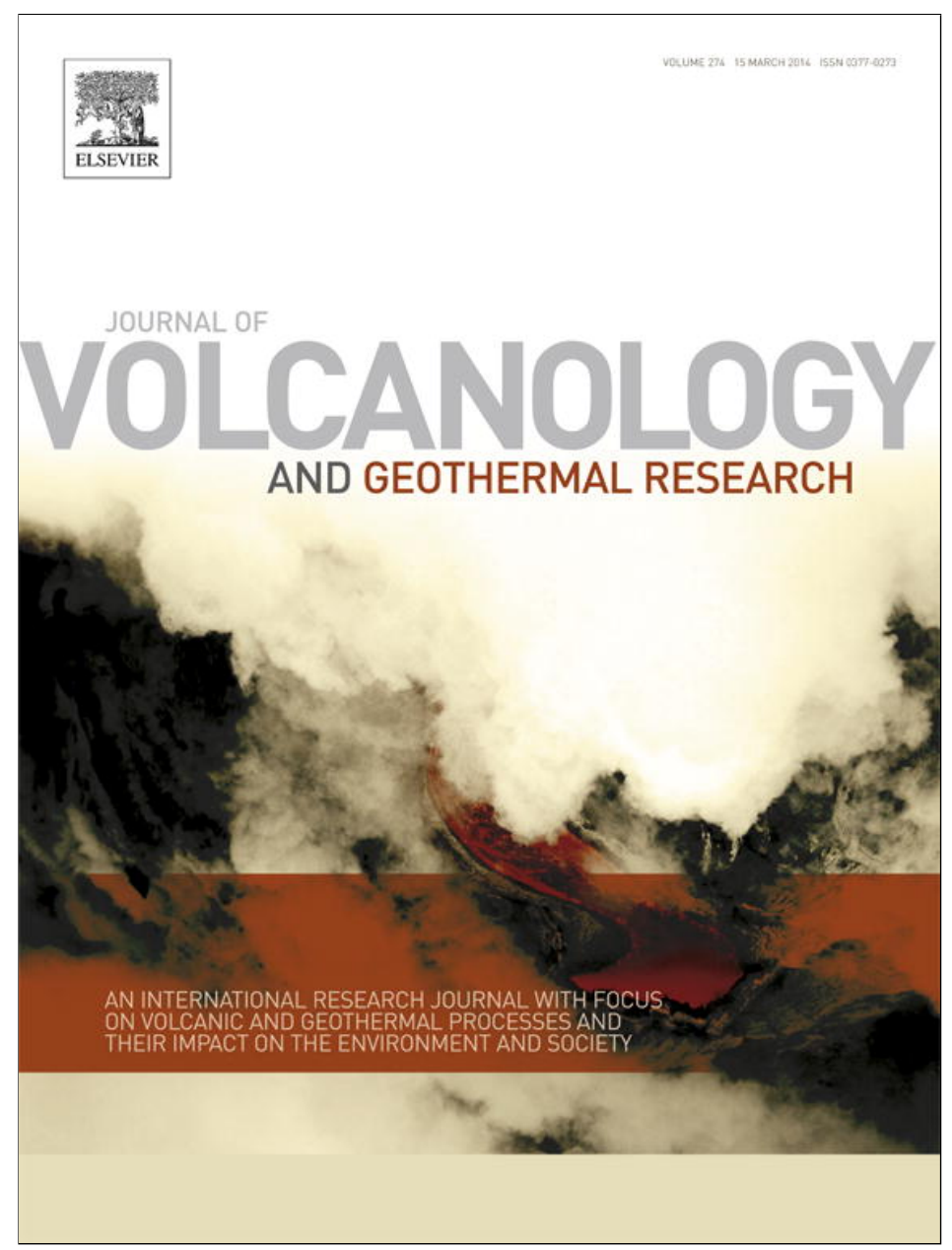

This article appeared in a journal published by Elsevier. The attached copy is furnished to the author for internal non-commercial research and education use, including for instruction at the authors institution and sharing with colleagues.

Other uses, including reproduction and distribution, or selling or licensing copies, or posting to personal, institutional or third party websites are prohibited.

In most cases authors are permitted to post their version of the article (e.g. in Word or Tex form) to their personal website or institutional repository. Authors requiring further information regarding Elsevier's archiving and manuscript policies are encouraged to visit:

http://www.elsevier.com/authorsrights 


\title{
The Domuyo volcanic system: An enormous geothermal resource in Argentine Patagonia
}

\author{
Giovanni Chiodini ${ }^{\text {a }}$, Caterina Liccioli ${ }^{\text {b,* }}$, Orlando Vaselli ${ }^{\text {c,d }}$, Sergio Calabrese ${ }^{\mathrm{e}}$, Franco Tassi ${ }^{\mathrm{c}, \mathrm{d}}$, Stefano Caliro ${ }^{\mathrm{a}}$, \\ Alberto Caselli ${ }^{\mathrm{b}, \mathrm{f}}$, Mariano Agusto ${ }^{\mathrm{f}}$, Walter D'Alessandro ${ }^{\mathrm{g}}$ \\ a Istituto Nazionale di Geofisica e Vulcanologia sezione di Napoli “Osservatorio Vesuviano," Via Diocleziano, Napoli 328-80124, Italy \\ ${ }^{\mathrm{b}}$ Instituto de Paleobiología y Geología de la Universidad Nacional Rio Negro, Rio Negro, Argentina \\ c Dipartimento di Scienze della Terra, Università di Firenze, Firenze, Italy \\ d CNR-Consiglio Nazionale delle Ricerche, Istituto di Geoscienze e Georisorse, Firenze, Italy \\ e Dipartimento di Scienze della Terra e del Mare, Università di Palermo, Palermo, Italy \\ ${ }^{\mathrm{f}}$ Facultad de Ciencias Exactas y Naturales, Universidad de Buenos Aires, Buenos Aires, Argentina \\ ${ }^{\mathrm{g}}$ Istituto Nazionale di Geofisica e Vulcanologia, Sezione di Palermo, Palermo, Italy
}

\section{A R T I C L E I N F O}

\section{Article history:}

Received 24 November 2013

Accepted 5 February 2014

Available online 15 February 2014

\section{Keywords:}

Domuyo volcano

Argentine Patagonia

Geothermal potential

Water geochemistry

\begin{abstract}
A B S T R A C T
A geochemical survey of the main thermal waters discharging in the southwestern part of the Domuyo volcanic complex (Argentina), where the latest volcanic activity dates to $0.11 \mathrm{Ma}$, has highlighted the extraordinarily high heat loss from this remote site in Patagonia. The thermal water discharges are mostly $\mathrm{Na}-\mathrm{Cl}$ in composition and have TDS values up to $3.78 \mathrm{~g} \mathrm{~L}^{-1}$ (El Humazo). A simple hydrogeochemical approach shows that 1,100 to $1,300 \mathrm{~kg} \mathrm{~s}^{-1}$ of boiling waters, which have been affected by shallow steam separation, flow into the main drainage of the area (Rio Varvarco). A dramatic increase of the most conservative species such as $\mathrm{Na}, \mathrm{Cl}$ and $\mathrm{Li}$ from the Rio Varvarco from upstream to downstream was observed and related solely to the contribution of hydrothermal fluids. The equilibrium temperatures of the discharging thermal fluids, calculated on the basis of the Na-K-Mg geothermometer, are between $190{ }^{\circ} \mathrm{C}$ and $230{ }^{\circ} \mathrm{C}$. If we refer to a liquid originally at $220{ }^{\circ} \mathrm{C}$ (enthalpy $=$ $944 \mathrm{~J} \mathrm{~g}^{-1}$ ), the thermal energy release can be estimated as high as $1.1 \pm 0.2 \mathrm{GW}$, a value that is much higher than the natural release of heat in other important geothermal fields worldwide, e.g., Mutnovsky (Russia), Wairakei (New Zealand) and Lassen Peak (USA). This value is the second highest measured advective heat flux from any hydrothermal system on Earth after Yellowstone.
\end{abstract}

(C) 2014 Elsevier B.V. All rights reserved.

\section{Introduction}

In tectonically young and active areas of the Earth, where meteoric waters infiltrate and circulate deeply, advective heat flux may be the dominant form of heat transfer and should be considered in the evaluation of the geothermal heat flux (e.g., Bodmer and Rybach, 1985; Čermak and Jetel, 1985; Gosnold, 1990; Bodri and Rybach, 1998; Brumm et al., 2009; Ingebritsen and Mariner, 2010; Chiodini et al., 2013). The magnitude and spatial distribution of heat flux are relevant for evaluating potential geothermal resources and also for inferring thermal the deep structure underlying volcanic areas, with reference to the nature and size of heat sources (such as magma or hot intrusive rocks) at depth (Manga, 1998). The fluid discharge rates of major thermal areas worldwide range from a few liters to several cubic meters of hot water per second (Taran and Peiffer, 2009). At Yellowstone Caldera (USA), the total discharge of the thermal waters was estimated to be

\footnotetext{
* Corresponding author. Tel.: + 541592984826048

E-mail address: caterina.liccioli@yahoo.it (C. Liccioli).
}

3,200 $\mathrm{L} \mathrm{s}^{-1}$ (Fournier, 1989). However, thermal discharges in other geothermal systems are rarely higher than $100 \mathrm{~L} \mathrm{~s}^{-1}$, this being for instance the reference value computed for pre-exploitation discharge at Wairakei (New Zealand; Ellis and Wilson, 1955). Thermal water flow rates of about $80 \mathrm{~L} \mathrm{~s}^{-1}$ were estimated at the Mutnovsky geothermal field in Kamchatka, Russia (Vakin and Pilipenko, 1986), while about $20 \mathrm{~L} \mathrm{~s}^{-1}$ of thermal water flow was measured at the Lassen Peak hydrothermal system (USA; Sorey, 1986). Others authors (Manga, 1998) stressed that cold or "slightly thermal" springs can also strongly affect the heat budget of a thermal zone, showing that in the central Oregon Cascades roughly half of the advective geothermal heat flux is discharged from springs only a few degrees above local ambient temperature.

In this work, we present the results of a geochemical survey carried out on boiling water discharges located at the remote volcano of Domuyo, a scarcely investigated volcanic complex from Argentine Patagonia (Fig. 1). Palacio and Llambias (1978) provided the first geochemical characterization of the Domuyo waters while other chemical data were reported in two internal reports produced by JICA $(1983 ; 1984)$ in the framework of a joint collaboration between the Government of 

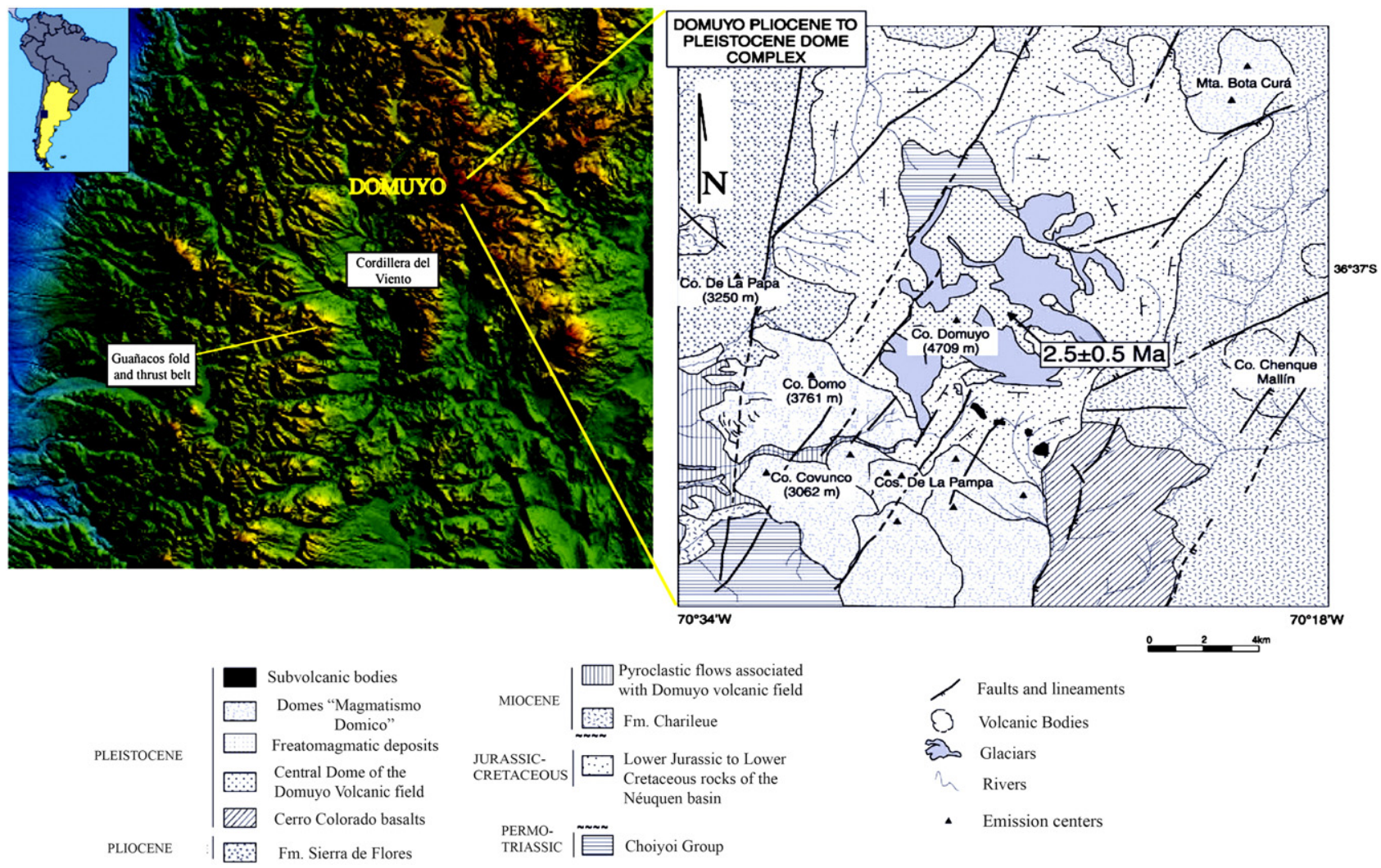

Fig. 1. (Left panel) The Domuyo volcanic complex, north of the Cordillera del Viento chain, and (right panel) geological map showing the distribution of Permian-Triassic to Pleistocene rocks; the arrow points to a K-Ar dating location (modified from Miranda et al., 2006).

Argentina and the Government of Japan to evaluate the geothermal resources in the area.

On the western slope of the Domuyo volcano, several boiling thermal springs discharge into roughly ENE-WSW-oriented creeks, which in turn flow into the main drainage system of the southwestern part of the volcanic edifice: the N-S-oriented Rio Varvarco (Fig. 2). A geochemical approach similar to those successfully applied to Yellowstone (Fournier, 1989) and El Chichon (Mexico, Taran and Peiffer, 2009) was performed in this sector of the Domuyo volcano in order to estimate its thermal release and geothermal potential. The thermal energy was computed by (i) evaluating the flux of chloride from the thermal source into the rivers and (ii) determining the original enthalpy and chloride content of the geothermal brines. Our results demonstrate that the thermal discharges account for a surprisingly high-energy release of $1.1 \pm 0.2 \mathrm{GW}$.

\section{Regional setting}

\subsection{Geological setting and volcanic activity}

The Domuyo volcanic complex ( $36^{\circ} 340 \mathrm{~S}, 70^{\circ} 250 \mathrm{~W}, 4,709 \mathrm{~m}$ high), nicknamed the "Roof of Patagonia," is Middle Miocene to Early Pliocene in age and is located at the northern edge of the Cordillera del Viento (Fig. 1), a chain uplifted during Cretaceous and Neogene times (Kay et al., 2006) that, together with the late Miocene to Quaternary Guañacos fold and thrust-belt mountain system (Suárez and Emparan, 1995, 1997) to its west, constitutes the main geological feature of the study area. At larger scale, the Domuyo volcano belongs to the southern volcanic zone (SVZ: $33^{\circ} \mathrm{S}$ to $46^{\circ} \mathrm{S}$ ), which has evolved for the last 20 Ma years by slightly dextral-oblique convergence between the Nazca and the South America plates at a rate of ca. 7-9 cm/year (Cembrano and Lara, 2009 and references therein).
The Domuyo volcano, with an estimated volume of $\sim 200 \mathrm{~km}^{3}$ and a base area of $138 \mathrm{~km}^{2}$ (Völker et al., 2011), is a broad structural dome and forms, together with three other tectonic domes, a major anticline, the "La Cruzada" high (Folguera et al., 2007). The geology of the area, initially studied by Groeber (1947), is made up of Permian-Triassic sedimentary and pyroclastic rocks (Choyoi Group) and acidic intrusive rocks, the latter intruding older formations. Jurassic and Cretaceous sedimentary and pyroclastic rocks unconformably overlie the basement (Spagnuolo et al., 2012). Tertiary andesitic volcanism covered the Mesozoic rocks and intrusive bodies emplaced close to the Domuyo volcano. Rhyolitic to dacitic tuff, lapilli tuff and lava flows cover its western slope. According to Mas et al. (2009), intrusive stocks are centered on the volcano and outcrop in an area of about $24 \mathrm{~km}^{2}$ at Domuyo, intruding the older sedimentary cover. Volcanism resumed in the late Pliocene to Quaternary during which time sub-volcanic bodies (K/Ar $2.5 \pm$ $0.5 \mathrm{Ma}$; Miranda, 1996, 2006) were also emplaced. The volcanic rocks surrounding the Domuyo volcano belong to two distinct magmatic series, originating from two different feeding magmas (Brousse and Pesce, 1982). One of these (Late Pliocene-Early Pleistocene) is calcalkaline and yielded andesitic rocks; the other (Middle Pleistocene) is represented by both shoshonitic and alkaline series and has formed dacitic and/or rhyolitic rocks of which the main expression is the Cerro Domo (absolute age $0.72 \pm 10$ Ma calculated on a rhyolitic lava flow; Brousse and Pesce, 1982), located on the southern slope of Domuyo. Younger volcanic products were dated between $0.55 \pm$ 0.10 and $0.11 \pm 0.02 \mathrm{Ma}$ (JICA, 1983) by the fission-track method, suggesting that Domuyo volcanism has been active through the Late Pleistocene.

\subsection{Hydrothermal activity}

This remote site in Patagonia has impressive signs and obvious evidence of high release of thermal energy. High flow rates (hundreds 

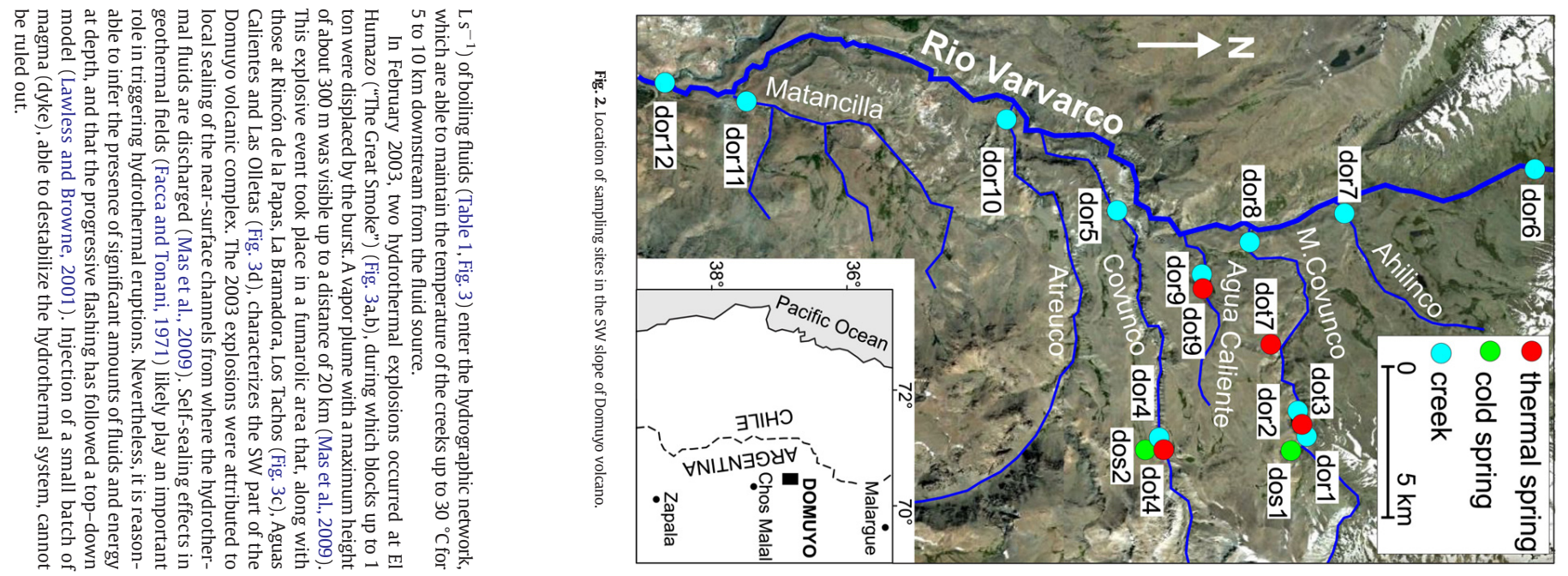

Table 1

Geographical coordinates, altitudes, flow rates, physico-chemical features and geochemical facies of the studied waters.

\begin{tabular}{|c|c|c|c|c|c|c|c|c|c|c|c|c|c|c|c|c|c|c|c|}
\hline \multirow[t]{2}{*}{ Sample } & \multirow[t]{2}{*}{ Locality } & \multirow[t]{2}{*}{ Type } & \multirow{2}{*}{$\frac{\text { Latitude }}{\text { UTM }}$} & \multirow{2}{*}{$\frac{\text { Longitude }}{\text { UTM }}$} & \multirow{2}{*}{$\frac{\text { Altitude }}{\mathrm{m}}$} & \multirow{2}{*}{$\frac{T}{{ }^{\circ} \mathrm{C}}$} & \multirow[t]{2}{*}{$\mathrm{pH}$} & \multirow{2}{*}{$\frac{\mathrm{EC}}{\mathrm{mS} / \mathrm{cm}}$} & \multirow{2}{*}{$\frac{\text { Flow rate }}{\mathrm{kg} \mathrm{s}^{-1}}$} & \multirow[t]{2}{*}{$\mathrm{Na}$} & \multirow[t]{2}{*}{$\mathrm{K}$} & \multirow[t]{2}{*}{$\mathrm{Mg}$} & $\mathrm{Ca}$ & \multirow[t]{2}{*}{ Li } & \multirow[t]{2}{*}{$\mathrm{Cl}$} & \multirow[t]{2}{*}{$\mathrm{HCO}_{3}$} & \multirow[t]{2}{*}{$\mathrm{SO}_{4}$} & \multirow{2}{*}{$\frac{\mathrm{TDS}}{\mathrm{g} \mathrm{kg}^{-1}}$} & \multirow[t]{2}{*}{ Composition } \\
\hline & & & & & & & & & & & & & $\overline{\mathrm{mg} \mathrm{kg}}-$ & & & & & & \\
\hline dor1 & Manchana Covunco & Creek & 361029 & 5942745 & 1,995 & 21.2 & 7.96 & 1,641 & nd & 169 & 17.8 & 7.74 & 113.0 & na & 245 & 115 & 129 & 0.80 & $\mathrm{Na}-\mathrm{Cl}$ \\
\hline dor2 & Manchana Covunco & Creek & 360826 & 5942649 & 1,952 & 48.5 & 8.01 & 3,860 & 800 & 526 & 53.8 & 3.04 & 92.9 & 5.08 & 799 & 100 & 257 & 1.84 & $\mathrm{Na}-\mathrm{Cl}$ \\
\hline dor4 & Covunco & Creek & 361863 & 5938249 & 2,038 & 37.2 & na & 3,100 & 840 & 462 & 44.4 & 3.30 & 168.3 & 4.23 & 722 & 84 & 220 & 1.71 & $\mathrm{Na}-\mathrm{Cl}$ \\
\hline dor5 & Covunco & Creek & 354135 & 5936607 & 1,541 & 23.1 & 8.15 & 2,506 & nd & 404 & 36.6 & 2.38 & 64.8 & 3.60 & 629 & 74 & 169 & 1.38 & $\mathrm{Na}-\mathrm{Cl}$ \\
\hline dor6 & Rio Varvarco & Rio & 352305 & 5950486 & 1,581 & 10.5 & 8.08 & 416 & 6,630 & 5.98 & 1.4 & 2.54 & 79.1 & 0.003 & 1.8 & 56 & 145 & 0.29 & $\mathrm{Ca}-\mathrm{SO}_{4}$ \\
\hline dor7 & Ahilinco & Creek & 356191 & 5945057 & 1,658 & 11.5 & 8.39 & 147 & nd & 14.9 & 2.5 & 4.89 & 10.9 & na & 17.2 & 55 & 1.02 & 0.11 & $\mathrm{Ca}-\mathrm{HCO}_{3}$ \\
\hline dor8 & Manchana Covunco & Creek & 355626 & 5942334 & 1,585 & 29.7 & 8.46 & 4,160 & 1,270 & 416 & 41.3 & 3.31 & 61.7 & na & 617 & 98 & 172 & 1.41 & $\mathrm{Na}-\mathrm{Cl}$ \\
\hline dor9 & Agua Caliente & Creek & 356362 & 5939441 & 1,739 & 47.8 & 7.23 & 4,800 & 87 & 454 & 28.4 & 1.57 & 24.4 & na & 704 & 112 & 62.2 & 1.39 & $\mathrm{Na}-\mathrm{Cl}$ \\
\hline dor10 & Atreuco & Creek & 355327 & 5935187 & 1,668 & 16.4 & 8.08 & 32 & nd & 3.1 & 0.7 & 0.56 & 3.1 & na & 0.5 & 15 & 0.94 & 0.02 & $\mathrm{Ca}(\mathrm{Na})-\mathrm{HCO}_{3}$ \\
\hline dor11 & Matancilla & Creek & 350995 & 5924804 & 1,301 & 21.2 & 8.47 & 49 & nd & 4.9 & 2.2 & 3.10 & 7.9 & na & 0.8 & 50 & 1.11 & 0.07 & $\mathrm{Ca}-\mathrm{HCO}_{3}$ \\
\hline dor12 & Rio Varvarco & Rio & 350368 & 5921396 & 1,184 & 18.0 & 8.04 & 875 & $12,700^{\S}$ & 97 & 9.1 & 1.72 & 67.1 & 0.78 & 149 & 56 & 133 & 0.51 & $\mathrm{Na}-\mathrm{Cl}$ \\
\hline dos1 & El Humazo & Cold spring & 361866 & 5942377 & 2,198 & 12.9 & 6.80 & 80 & nd & 3.1 & 1.3 & 0.85 & 4.5 & nd & 0.4 & 28 & 1.39 & 0.04 & $\mathrm{Ca}-\mathrm{HCO}_{3}$ \\
\hline dos2 & Los Tachos & Cold spring & 361906 & 5938262 & 2,050 & 8.1 & na & 78 & nd & 13.7 & 1.2 & 0.34 & 3.9 & 0.10 & 19.1 & 15 & 3.1 & 0.06 & $\mathrm{Na}-\mathrm{Cl}$ \\
\hline dot3 & El Humazo & Thermal spring & 361002 & 5942747 & 1,991 & 97.2 & 8.32 & 9,600 & nd & 1280 & 129.0 & 0.07 & 37.5 & 12.37 & 2020 & 78 & 219 & 3.78 & $\mathrm{Na}-\mathrm{Cl}$ \\
\hline $\operatorname{dot} 4$ & Los Tachos & Thermal spring & 361901 & 5938273 & 2,043 & 96.2 & na & na & nd & 1160 & 67.5 & 0.60 & 58.7 & 11.16 & 1820 & 119 & 187 & 3.42 & $\mathrm{Na}-\mathrm{Cl}$ \\
\hline dot7 & Las Olletas & Thermal spring & 358400 & 5941715 & 1,870 & 97.0 & 8.00 & 7,860 & nd & 1020 & 57.0 & 0.51 & 36.1 & 9.91 & 1590 & 102 & 160 & 2.98 & $\mathrm{Na}-\mathrm{Cl}$ \\
\hline $\operatorname{dot} 9$ & Agua Caliente & Thermal spring & 356511 & 5939451 & 1,762 & 67.5 & 6.81 & 4,600 & nd & 630 & 40.3 & 1.04 & 26.7 & 5.54 & 945 & 103 & 96 & 1.85 & $\mathrm{Na}-\mathrm{Cl}$ \\
\hline
\end{tabular}

= not analyzed; $\mathrm{nd}=$ not determined; $\mathrm{EC}=$ electrical conductivity.

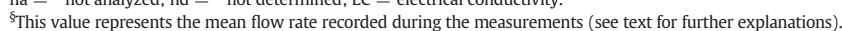




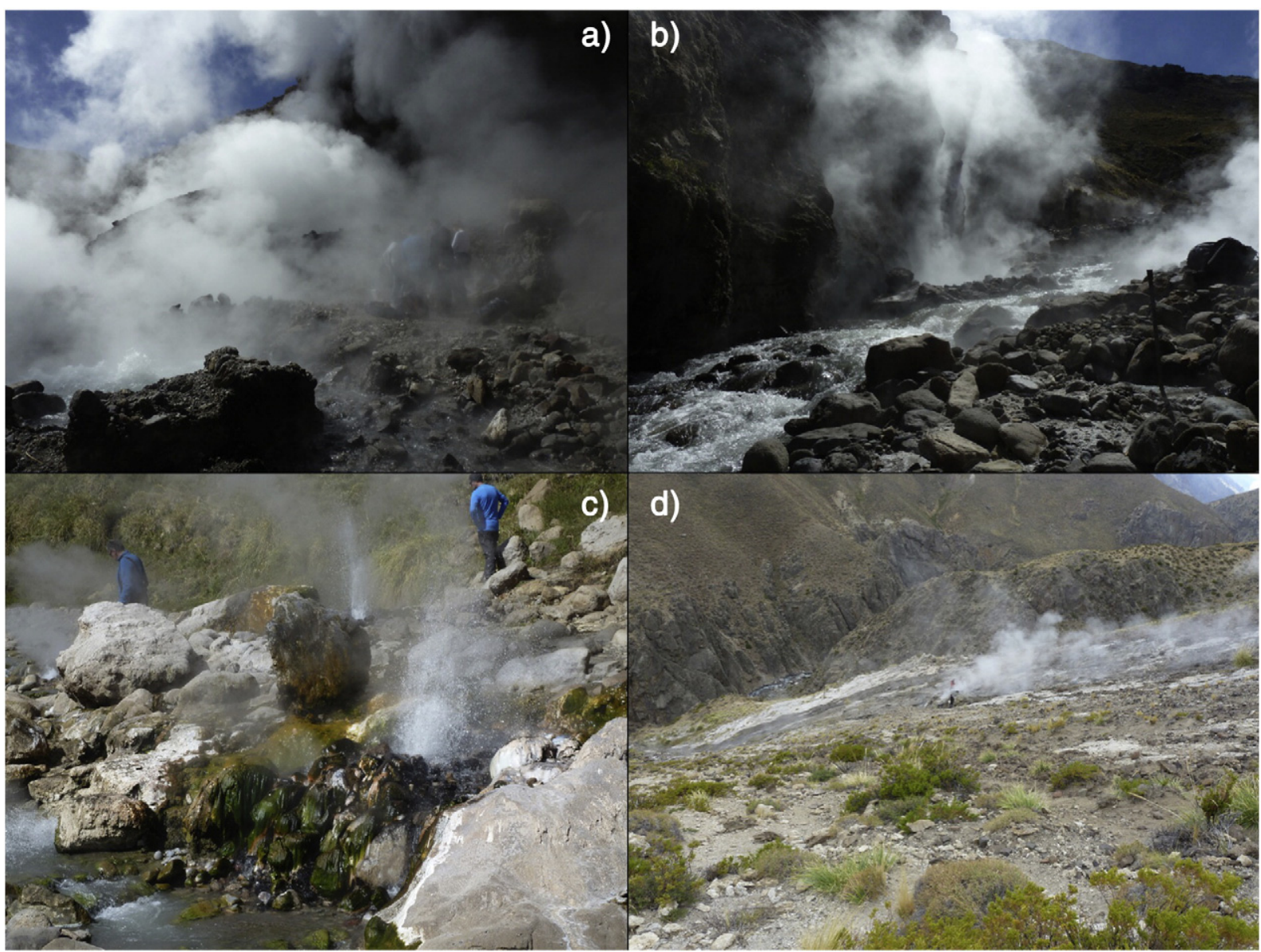

Fig. 3. Images of thermal discharge from the SW slope of Domuyo volcano: (a and b) El Humazo; (c) Los Tachos; (d) Las Olletas.

\section{Material and methods}

A survey of the thermal features of the SW part of Domuyo volcano, where the 2003 hydrothermal explosions occurred, was performed in March 2013 by an Argentine-Italian team. This sector of the volcano was previously recognized (Palacio and Llambias, 1978) as the site of an important hydrothermal activity characterized by many thermal discharges, among which we selected the main ones. In particular, four thermal springs from El Humazo (dot3), Los Tachos (dot4), Las Olletas (dot7) and Agua Caliente (dot7) were sampled and analyzed for the main chemical compounds, as was Rio Varvarco upstream (dor6) and downstream (dor12) of the hot water inflow and the main creeks (from north to the south, Ahilinco: dor7; Manchana Covunco: dor1, dor2, dor8; Agua Caliente: dor9, Covunco: dor4, dor5; Atreuco: dor10; Matancilla: dor11) discharging into the Rio Varvarco. Two cold springs discharging close to El Humazo (dos1) and Los Tachos (dos2) (Fig. 2) were also sampled.

Temperature, $\mathrm{pH}$ and electrical conductivity were measured in the field. Water samples were filtered using $0.45 \mu \mathrm{m}$ filters and collected in 125 and $50 \mathrm{~mL}$ polyethylene bottles for the determination of anions $\left(\mathrm{HCO}_{3}, \mathrm{Cl}, \mathrm{SO}_{4}\right)$ and cations $\left(\mathrm{Na}, \mathrm{K}, \mathrm{Ca}, \mathrm{Mg}, \mathrm{NH}_{4}\right.$ and $\left.\mathrm{Li}\right)$. The latter aliquot was acidified with $0.5 \mathrm{~mL}$ of ultrapure $\mathrm{HCl}(30 \%)$. Bicarbonate was determined by acidimetric titration with $0.01 \mathrm{~N} \mathrm{HCl}$, using methylorange as indicator. Anions and cations were determined by ion chromatography using a Dionex ICS-3000 at the Laboratory of Istituto Nazionale di Geofisica e Vulcanologia (Naples, Italy). All determinations were referred to standard solutions calibrated versus NIST Standard Reference Materials. All the laboratory analytical methods and the alkalinity determinations have accuracy better than $3 \%$.
Flow rate measurements were made in Rio Varvarco, upstream (dor6) and downstream (dor7) of the thermal inflow, and in the thermally heated creeks (dor5, dor8 and dor9). Owing to the unavailability of standard stream gaging equipment, flow rates were calculated in suitable sections using the float method. Selected sections of each river were measured in detail, and the water velocity was then computed as the average of 10 or more values obtained by measuring the travel time of a float across a fixed distance (generally, 10 to $20 \mathrm{~m}$ ). The maximum uncertainty of the flow rate measurement of dor12 (Rio Varvarco downstream) deserves further explanations because this measurement is used to estimate the total energy release of Domuyo geothermal system. The cross section of dor12 is shown in Fig. 4 where the mean superficial velocity of the entire section $\left(1.54 \mathrm{~m} \mathrm{~s}^{-1}\right)$, of the central fastest zone $\left(1.89 \mathrm{~m} \mathrm{~s}^{-1}\right)$ and of the two lateral zones of lower velocity $\left(1.33 \mathrm{~m} \mathrm{~s}^{-1}\right)$ is shown. In our computation, we assumed the flow rates computed with the lower and higher velocity as reasonable limits of the measurement uncertainty $\left(11,000\right.$ and $\left.15,700 \mathrm{~kg} \mathrm{~s}^{-1}\right)$. This range will be used to quantify the uncertainty of the thermal energy release

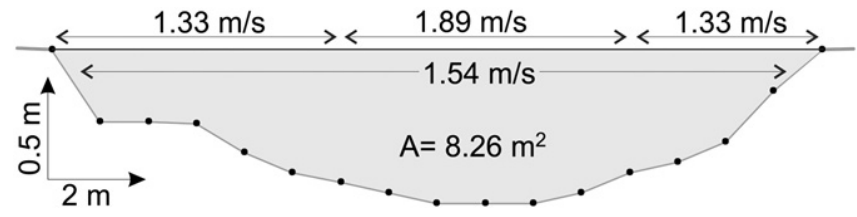

Fig. 4. The outflow area $\left(A\right.$ in $\left.\mathrm{m}^{2}\right)$ of the Rio Varvarco (dot12 in Table 1$)$ and the velocities $(\mathrm{v}$ in $\mathrm{m} / \mathrm{s})$ used to calculate the flow rate $(Q)$ and its uncertainties by $Q=A \times v$ (see text for explanation). 
estimated by the $\mathrm{Cl}$-inventory method. The basis of the $\mathrm{Cl}$-inventory method is simultaneous measurement of flow rate and chemical composition of streams and rivers at specific sampling locations. Most high-chloride hot springs in non-arid regions occur near perennial streams that eventually capture most of the thermal fluid (Taran and Peiffer, 2009). The total discharge from hot-spring areas can be monitored on the basis of downstream increases in the solute loads of nearby streams, chloride being the most conservative element with which thermal waters are usually enriched relative to nearby surface and/or shallow ground waters.

\section{Results}

Dot3, dot 4 and dot7 thermal springs discharge between 1,870 and 2,040 $\mathrm{m}$ of altitude and have boiling temperatures (up to $97^{\circ} \mathrm{C}$ ) and alkaline $\mathrm{pH}$ (slightly higher than 8 ), while dot9 has a temperature of $67.5^{\circ} \mathrm{C}$ and a pH value of 6.8. Salinities (expressed as TDS, Total Dissolved Solids) are 3.78, 3.42 and $2.98 \mathrm{~g} \mathrm{~kg}-1$, respectively. Agua Caliente (dot9) discharges at $1,792 \mathrm{~m}$ and has lower temperature $\left(67.5^{\circ} \mathrm{C}\right), \mathrm{pH}$ (6.81) and salinity $\left(1.85 \mathrm{~g} \mathrm{~kg}^{-1}\right)$ lower than the other thermal waters. All the thermal waters have a $\mathrm{Na}-\mathrm{Cl}$ composition (Table 1). A similar composition is observed for the creeks (dor1, dor2, dor4, dor5, dor8, dor9 and dor12) into which these thermal waters discharge. Nevertheless, their salinity (from 0.06 to $1.8 \mathrm{~g} \mathrm{~kg}^{-1}$ ) is lower thermal springs due to dilution processes affecting the thermal component.

Samples dor7, dor10, dor 11 and dos 1 are characterized by a $\mathrm{Ca}(\mathrm{Na})-$ $\mathrm{HCO}_{3}$ composition and low salinities $\left(\leq 0.11 \mathrm{~g} \mathrm{~L}^{-1}\right)$, while only sample

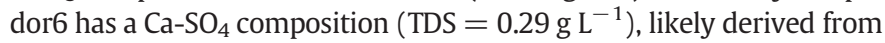
the dissolution of the gypsum present upstream of the surveyed area (Palacio and Llambias, 1978).

The calculated flow rates for dor2, dor4, dor6, dor8, dor9 and dor12 are reported in Table 1 . The highest value was recorded at Rio Varvarco downstream (dor12, mean value: $12,700 \mathrm{~kg} \mathrm{~s}^{-1}$ ) where all the tributaries, including those that collect the thermal waters, have coalesced.

\section{Discussion}

\subsection{Water chemistry and geothermometry}

Equilibrium reservoir temperatures were calculated for the main thermal water discharges, i.e., El Humazo $\left(\operatorname{dot} 3, T=97^{\circ} \mathrm{C}\right)$, Los Tachos ( $\left.\operatorname{dot} 4, T=96{ }^{\circ} \mathrm{C}\right)$, Las Olletas $\left(\operatorname{dot} 7, T=97{ }^{\circ} \mathrm{C}\right.$ ) and Agua Caliente ( $\operatorname{dot} 9, \mathrm{~T}=67.5^{\circ} \mathrm{C}$ ) (Table 1 ). These Na-Cl thermal waters have chloride contents from $950 \mathrm{mg} \mathrm{kg}^{-1}$ (dot9) to $2,000 \mathrm{mg} \mathrm{kg}^{-1}$ (dot3). Samples dot3, dot4 and dot7 are at boiling point and are affected by shallow steam separation, which likely increases their original $\mathrm{Cl}$ content.

This is particularly evident at El Humazo spring where there are nearby steam vents (Fig. 3a,b). During steam separation, $\mathrm{CO}_{2}$ is lost, causing an increase in $\mathrm{pH}$ (up to 8.3 in dot3) and precipitation of $\mathrm{CaCO}_{3}$, as testified by the presence of travertine deposits. At El Humazo, travertine forms a deposit of $500 \times 200 \mathrm{~m}$ with a maximum thickness of $50 \mathrm{~m}$ (Mas et al., 2009). Steam separation does not seem to affect Agua Caliente, the temperature of which is below the boiling point and which is characterized by the lowest chloride content ( $950 \mathrm{mg} \mathrm{kg}^{-1}$ ) among the studied thermal waters. Agua Caliente can be considered as derived by mixing between the original thermal component and cold groundwater. Despite the possible steam separation or mixing processes, the four thermal waters are suitable for application of the $\mathrm{Na}-\mathrm{K}-\mathrm{Mg}$ geothermometer because of their very low $\mathrm{Mg}$ contents (from 0.07 to $1 \mathrm{mg} \mathrm{kg}^{-1}$ ), which are compatible with a "mature" geothermal liquid (Giggenbach, 1988). This geothermometric method compares, in a triangular diagram, the relative proportions of the measured values (in $\mathrm{mg} \mathrm{kg}^{-1}$ ) with the theoretical ratios among $\mathrm{Na}, \mathrm{K}$ and $\mathrm{Mg}^{1 / 2}$ evaluated for different temperatures (Fig. 5; Giggenbach, 1988). The theoretical

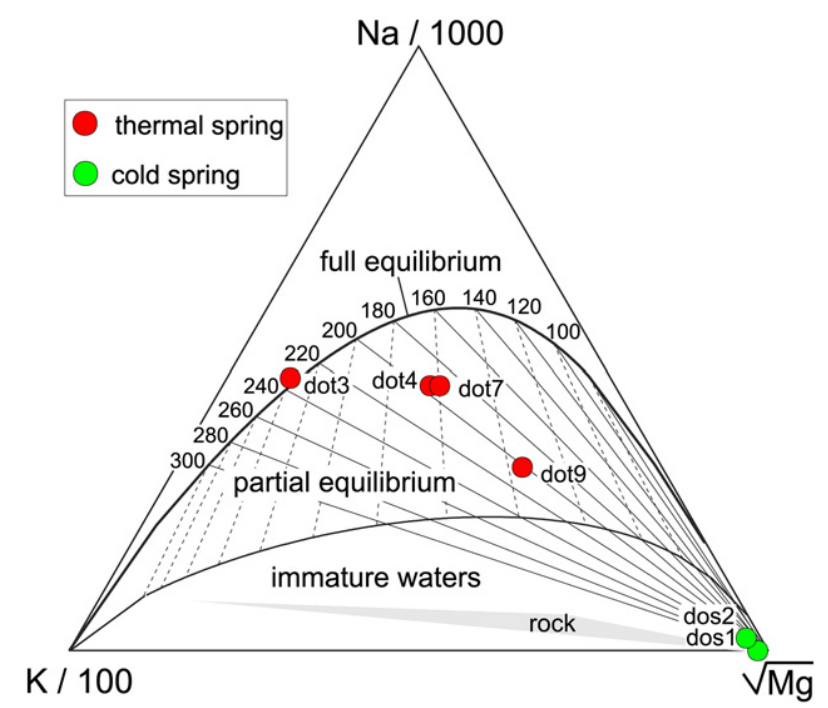

Fig. 5. The Na-K-Mg geothermometric triangular diagram (Giggenbach, 1988) and the Domuyo thermal waters. Cold waters dos1 and dos2 are reported for comparison.

values refer to a solution in equilibrium with a typical hydrothermal mineral assemblage that considers the following reactions:

$\mathrm{K}-$ feld $+\mathrm{Na}^{+}=\mathrm{Na}-$ feld $+\mathrm{K}^{+}$

$2.8 \mathrm{~K}$-feld $+1.6 \mathrm{H}_{2} \mathrm{O}+\mathrm{Mg}^{2+}=0.8 \mathrm{~K}$-mica +0.2 Chlorite

$$
+5.4 \mathrm{SiO}_{2}+2 \mathrm{~K}^{+}
$$

These reactions refer to a mineralogical assemblage when an isochemical equilibrium is achieved. The $\mathrm{Na} / \mathrm{K}$ and the $\mathrm{K}^{2} / \mathrm{Mg}$ ratios depend on temperature according to

$T\left({ }^{\circ} \mathrm{C}\right)=\{1390 /[1.75+\log (\mathrm{Na} / \mathrm{K})]\}-273.15$

$T\left({ }^{\circ} \mathrm{C}\right)=\{4410 /[14.0-\log (\mathrm{K} 2 / \mathrm{Mg})]\}-273.15$

The intersection of each $\mathrm{Na}-\mathrm{K}$ and $\mathrm{K}-\mathrm{Mg}$ isotherm corresponds to water compositions in equilibrium with a mineralogical assemblage that controls both geothermometers and delineates the so-called "full equilibrium" curve. In Fig. 5, the fields of partial equilibrium and immature waters are also delineated. Because of the fast kinetics of the reactions involving Mg, Eq. (4) can quickly equilibrate at the decreasing temperatures encountered by a geothermal liquid ascending toward the surface, displacing the points in Fig. 5 toward the Mg corner. The effect is similar to that caused by mixing of the thermal component with shallow cold groundwater which, relative to the geothermal liquids, is enriched in Mg. However, such secondary processes do not substantially change the temperature estimates based on the Na-K geothermometer, the latter providing reliable estimation of the temperature of the original thermal liquid. The Domuyo thermal waters lie either along the "full equilibrium" curve (dot3) or in the "partial equilibrium" field (dot4, dot7, dot9), indicating $\mathrm{Na} / \mathrm{K}$ temperatures of $233{ }^{\circ} \mathrm{C}$ (dot3), $192{ }^{\circ} \mathrm{C}(\operatorname{dot} 4), 190{ }^{\circ} \mathrm{C}(\operatorname{dot} 7)$ and $199{ }^{\circ} \mathrm{C}(\operatorname{dot} 9)$. As suggested by the relatively low $\mathrm{Cl}$ content and emergence temperature, dot9 (Agua Caliente) is likely sourced by a thermal system that mixes with shallow cold groundwater of composition similar to samples dos1 and dos2 (Fig. 5). The other thermal springs, which emerge at the boiling point, plot close to the full equilibrium curve. In these cases, the significant 
secondary process is loss of steam during boiling, which does not affect the $\mathrm{Na} / \mathrm{K}$ ratio, but increases the absolute concentrations of ions.

\subsection{Flux of the geothermal liquid in the Rio Varvarco and its tributaries and} computation of the total thermal release

The relatively alkaline $\mathrm{pH}$ values and high $\mathrm{Cl}$ concentrations suggest that the Domuyo thermal waters may be affected by steam loss during boiling. Such a process is particularly evident for dot3 (El Humazo) where vigorous vapor vents accompany the water discharge (Fig. 3a, b). According to Mas et al. (2009), the emitted gas consists of $99 \%$ of steam and $1 \%$ of other gases, among which $\mathrm{CO}_{2}$ is the most abundant (JICA, 1983).

Assuming an iso-enthalpic boiling process, the fractions of separated steam (from 0.17 to 0.26 ) were subsequently used to restore the original composition of the un-boiled liquid by referring to the mobile species $\left(\mathrm{Cl} \sim 1,500 \mathrm{mg} \mathrm{kg}^{-1}\right.$, $\mathrm{Na} \sim 950 \mathrm{mg} \mathrm{kg}^{-1}$, $\mathrm{Li} \sim 9.2 \mathrm{mg} \mathrm{kg}^{-1}$ for dot3 and dot4, and $\mathrm{Cl} \sim 1,300 \mathrm{mg} \mathrm{kg}^{-1}, \mathrm{Na} \sim 850 \mathrm{mg} \mathrm{kg}^{-1}, \mathrm{Li} \sim 8.2 \mathrm{mg} \mathrm{kg}^{-1}$ for dot2). The restored compositions of the three samples are similar and in particular those of sample dot 3 and dot 4 are practically the same. The restored concentration of $\mathrm{Cl}$ from dot 3 and dot4, which are characterized by the highest flow rate, is our reference concentration for the un-boiled liquid and is assumed as the minimum concentration in computation of the thermal energy. The measured $\mathrm{Cl}$ concentration of dot3 $\left(2,000 \mathrm{mg} \mathrm{kg}^{-1}\right)$ was considered as the maximum concentration of the original geothermal liquid, assuming a non-isenthalpic process where the cooling of the water is governed by heat exchange with the rocks, without any steam separation.

The conservative behavior of $\mathrm{Na}, \mathrm{Cl}$ and $\mathrm{Li}$ may allow use of these solutes as tracers of the thermal component flux in Rio Varvarco and its tributaries. We assumed that $\mathrm{Cl}, \mathrm{Na}$ and Li contents increase from Rio Varvarco upstream (dor6) to Rio Varvarco downstream (dor12) is due to the hot waters in the tributaries, i.e., Manchana Covunco (dor8: $29.7^{\circ} \mathrm{C}, 4,160 \mu \mathrm{S} / \mathrm{cm}$ ), Agua Caliente (dor9: $47.8^{\circ} \mathrm{C}, 4,800 \mu \mathrm{S} / \mathrm{cm}$ ) and Covunco (dor5: $23.1{ }^{\circ} \mathrm{C}, 2,510 \mu \mathrm{S} / \mathrm{cm}$ ). The other tributaries have ambient temperature and lower salinity as suggested by their low electrical conductivity (dor7: Ahilinco $11.5{ }^{\circ} \mathrm{C}, 147 \mu \mathrm{S} / \mathrm{cm}$; dor10, Atreuco $16.4{ }^{\circ} \mathrm{C}, 32 \mu \mathrm{S} / \mathrm{cm}$; dor11, Matansilla: $21.1{ }^{\circ} \mathrm{C}, 49 \mu \mathrm{S} / \mathrm{cm}$ ).

Qualitatively the mixing between the thermal component and the low salinity waters is indicated by the very high positive correlations $\left(R^{2}=0.999\right)$ among $\mathrm{Na}, \mathrm{Cl}$ and $\mathrm{Li}$, as shown in Fig. 6a,b. In these figures, the computed $\mathrm{Cl}$ concentration of the pre-boiled geothermal liquid is also shown.

The fluxes of $\mathrm{Na}, \mathrm{Cl}$ and $\mathrm{Li}$ were computed by multiplying their concentrations by the respective flow rates measured at Rio Varvarco (upstream and downstream) and Manchana Covunco, Agua Caliente and Covunco hot creeks. For each species, the sum of the creek fluxes (Na: $960 \mathrm{~g} \mathrm{~s}^{-1} ; \mathrm{Cl}: 1,450 \mathrm{~g} \mathrm{~s}^{-1}$; $\mathrm{Li}: 8.5 \mathrm{~g} \mathrm{~s}^{-1}$ ) is systematically lower than those computed in the Rio Varvarco as the difference between the downstream and upstream values (Na: $1,190 \mathrm{~g} \mathrm{~s}^{-1} ; \mathrm{Cl}: 1,880 \mathrm{~g} \mathrm{~s}^{-1}$; $\mathrm{Li}$ : $9.9 \mathrm{~g} \mathrm{~s}^{-1}$ ). This systematic difference, though less than $25 \%$, could be due to some uncertainties in the flow rate computation. Alternatively, part of the creek water may be lost as infiltration into the permeable alluvial deposits but later seeps into the river downstream from the confluence or some groundwater inflow to the Rio that includes a thermal component. Nevertheless, we think that the observed differences are acceptable. Assuming that the flux calculated for Rio Varvarco is the most reliable, the computation of the thermal energy release $(\mathrm{QH})$ and related uncertainties were performed using the simple relation:

$Q_{\mathrm{H}}=\left(Q_{\mathrm{Cl}} / \mathrm{Cl}_{\mathrm{t}}\right) \times H_{\mathrm{t}}$

where $Q_{\mathrm{Cl}}$ is the flux of $\mathrm{Cl}$ in the river $\left(\mathrm{g} \mathrm{s}^{-1}\right), \mathrm{Cl}_{\mathrm{t}}$ is the $\mathrm{Cl}$ concentration in the original thermal liquid $\left(\mathrm{g} \mathrm{g}^{-1}\right.$, the unity has been converted from $\mathrm{mg} \mathrm{kg}^{-1}$ ) and $H_{\mathrm{t}}$ is the enthalpy $\left(\mathrm{Jg}^{-1}\right.$ ) of the liquid at the estimated reservoir temperature.
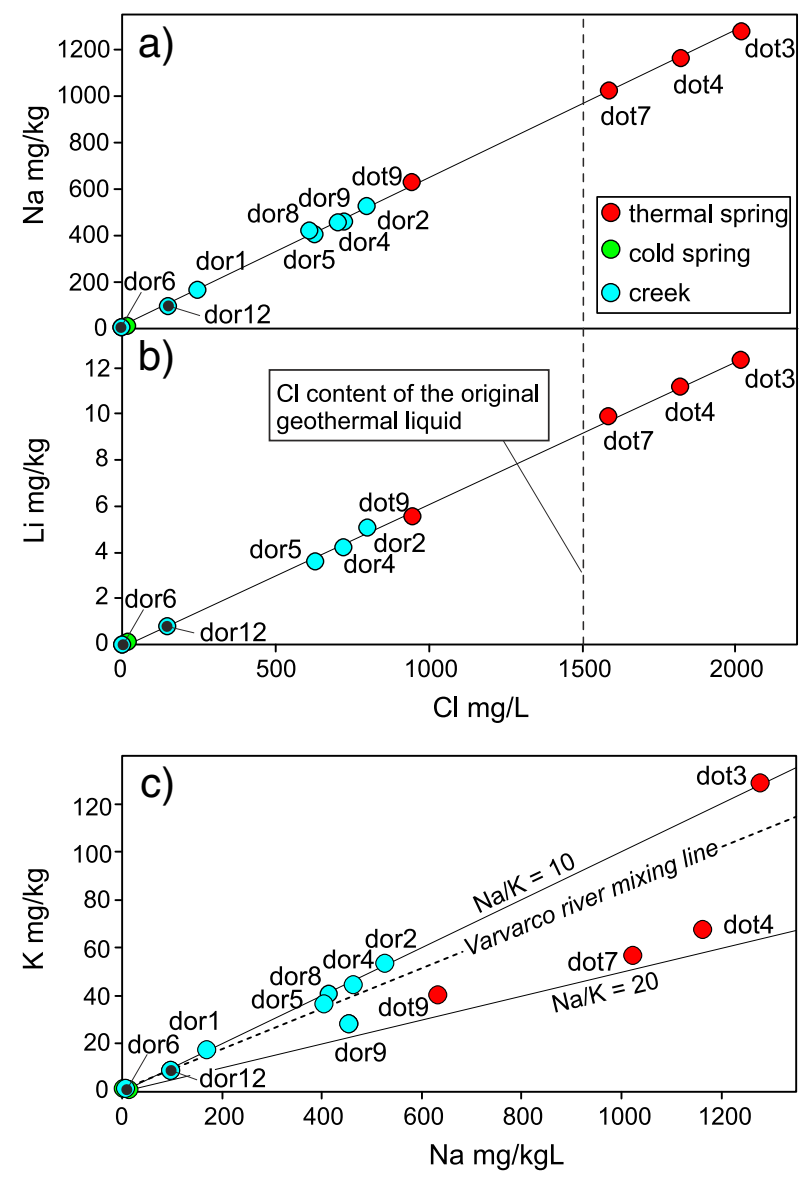

Fig. 6. Binary diagrams (a) Na vs. Cl, (b) Li vs. $\mathrm{Cl}$ and (c) Na vs. K. Symbols as in Fig. 2 . The unlabelled samples are diluted waters close to the axis origin in each diagram.

We solved Eq. (5) with a Monte Carlo procedure considering the uncertainties of the flow rate of Rio Varvarco $\left(11,000\right.$ and $\left.15,700 \mathrm{~kg} \mathrm{~s}^{-1}\right)$ and of $\mathrm{Cl}_{\mathrm{t}}\left(1.5-2.0 \mathrm{~g} \mathrm{~kg}^{-1}\right)$. The enthalpy $H_{\mathrm{t}}$ was computed for an original temperature of $220{ }^{\circ} \mathrm{C} \pm 10{ }^{\circ} \mathrm{C}$ (enthalpy $=944 \mathrm{~J} \mathrm{~g}^{-1} \pm$ $46 \mathrm{~J} \mathrm{~g}^{-1}$ ), i.e., the temperature resulting from the average $\mathrm{Na} / \mathrm{K}$ ratio of the thermal tributaries which enter Rio Varvarco as reported in the Na-K diagram of Fig. 6c. The Monte Carlo simulation gives a thermal water total discharge of $1,150 \pm 150 \mathrm{~kg} \mathrm{~s}^{-1}$ and a thermal energy release of $1.1 \times 10^{9} \pm 0.2 \times 10^{9} \mathrm{~W}(1.1 \pm 0.2 \mathrm{GW})$.

\section{Conclusion}

A geochemical survey of the main thermal waters discharging in the southwestern part of the Domuyo volcanic complex has highlighted the strikingly high thermal energy release from this remote site in Patagonia. A simple hydrogeochemical approach shows that $\sim 1,150 \mathrm{~kg} \mathrm{~s}^{-1}$ of boiling water is conveyed to the main drainage system (Rio Varvarco) through its tributaries. Referring to a liquid originally at $220^{\circ} \mathrm{C}$, the calculated thermal energy release is as large as $\sim 1.1 \mathrm{GW}$, a value that, to the best of our knowledge, is the second largest advective heat flux ever measured from a single onland volcanic center (other than Yellowstone). This result suggests an enormous geothermal potential of the Domuyo system, which has yet to be exploited.

A previous geochemical survey of the same thermal waters, performed in 1976 (Llambías et al., 1978), reports chemical compositions, temperatures and thermal features similar to those measured in our work, suggesting a persistent heat flux. In addition to local sealing of hydrothermal channels, this large flux of energy may be the main reason 
for the 2003 hydrothermal explosions at El Humazo. Finally, this very large heat flux is somewhat hard to explain in terms of either the cooling of mapped magmatic intrusions, which seem to have occurred at $0.72 \mathrm{Ma}$, or the most recent volcanic activity at $0.11 \mathrm{Ma}$. In our opinion, the presence of an undocumented, younger volcanic activity cannot be excluded. Alternatively, the high heat flux may originate from a magma intrusion at shallow depth, possibly related to a recent reactivation of the Domuyo volcanic system.

\section{Acknowledgements}

The authors are gratefully to the personnel of the Domuyo Provincial Park and to our guide Paulo Fanti. Many thanks are due to the four Brazilian students (Vanessa Araujo, Cristiane Schmidt, Marcello Cappelli and Hugo Vidal) who accompanied and helped us during the fieldwork. The authors thank William C. Evans and an anonymous reviewer for their useful comments and suggestions on the early version of the manuscript.

\section{References}

Bodmer, Ph., Rybach, L., 1985. Heat flow maps and deep ground water circulation: examples from Switzerland Original. J. Geodyn. 4, 24-233.

Bodri, B., Rybach, L., 1998. Influence of topographically driven convection on heat flow in the Swiss Alps: a model study. Tectonophysics 291, 19-27.

Brousse, R., Pesce, A.H., 1982. Cerro Domo: un volcán cuartario con posibilidades geotérmicas, Provincia del Neuquén. $9^{\circ}$ Congreso Latinoamericano de Geología (Buenos Aires). Actas, 4, pp. 197-208 (Buenos Aires (Argentina)).

Brumm, M., Wang, C.Y., Manga, M., 2009. Spring temperatures in the Sagehen Basin, Sierra Nevada, CA: implications for heat flow and groundwater circulation. Geofluids 9, 195-207.

Cembrano, J., Lara, L., 2009. The link between volcanism and tectonics in the southern volcanic zone of Chilean Andes: A review. Tectonophysics 471, 96-113.

Čermak, V., Jetel, J., 1985. Heat flow and ground water movement in the Bohemian Cretaceous basin (Czechoslovakia) Original. J. Geodyn. 4, 285-303.

Chiodini, G., Cardellini, C., Caliro, S., Chiarabba, C., Frondini, F., 2013. Advective heat transport associated to regional Earth degassing in central Apennine (Italy). Earth Planet. Sci. Lett. 373, 65-74

Ellis, A.J., Wilson, S.H., 1955. The heat from Wairakei-Taupo thermal region calculated from the chloride output. N. Z. J. Sci. Technol. Sect. B 36, 622-631.

Facca, G., Tonani, F., 1971. The self-sealing geothermal field. Bull. Volcanol. 30, 271-273.

Folguera, A., Ramos, V.A., Zapata, T., Spagnuolo, M.G., 2007. Andean evolution at the Guañacos and Chos Malal fold and thrust belts ( $\left.36^{\circ} 30^{\prime}-37^{\circ} \mathrm{S}\right)$. J. Geodyn. 44, 129-148.

Fournier, R.O., 1989. Geochemistry and dynamics of the Yellowstone National Park hydrothermal system. Ann. Rev. Earth Planet. Sci. 17, 13-53.

Giggenbach, W.F., 1988. Geothermal solute equilibria. Derivation of $\mathrm{Na}-\mathrm{K}-\mathrm{Mg}-\mathrm{Ca}$ geoindicators. Geochim. Cosmochim. Acta 52, 2749-2765.

Gosnold, W.D., 1990. Heat flow in the Great Plains of the United States. J. Geophys. Res. 95, 353-374.
Groeber, P., 1947. Hojas Domuyo, Mari Mahuida, Huahuar Co y parte de Epu Lauquen. Observaciones Geológicas a lo largo del Meridiano 70. Asociación Geológica Argentina. Serie Reimpresiones 1, 75-136 (1980).

Ingebritsen, S.E., Mariner, R.H., 2010. Hydrothermal heat discharge in the Cascade Range, northwestern United States. J. Volcanol. Geotherm. Res. 196, 208-218.

JICA, 1983. Argentine Republic. Final Report on the Northern Neuquen Geothermal Development Project. First-Second Phase Survey. No 25.

JICA, 1984. Argentine Republic. Final Report on the Northern Neuquen Geothermal Development Project. Third Phase Survey. No 25.

Kay, S., Burns, W., Copeland, P., Mancilla, O., 2006. Upper Cretaceous to Holocene magmatism and evidence for transient Miocene shallowing of the Andean subduction zone under the northern Neuquen basin. In: Kay, S.M., Ramos, V.A. (Eds.), Late Cretaceous to Recent Magmatism and Tectonism of the Southern Andean Margin at the Latitude of the Neuquen Basin (36-39 S). Geol. Soc. Am. Special paper, 407, pp. 19-60.

Lawless, J.V., Browne, P.R.L., 2001. Hydrothermal eruptions: mechanisms implications for Prediction. Proceedings 23rd New Zealand Geothermal Workshop 2001 51-56.

Llambías, E., Palacios, M., Danderfer, J.C., Brogioni, N., 1978. Las rocas ígneas Cenozoicas del Volcán Domuyo y áreas adyacentes. Actas VII Congreso Geológico Argentino Neuquén, 2, pp. 569-584

Manga, M., 1998. Advective heat discharge by low-temperature discharge in the Oregon Cascades. Geology 26, 1,813-1,816.

Mas, G.R., Bengochea, L., Mas, L.C., Lopez, N., 2009. Hydrothermal explosion due to seal effect in el Humazo geothermal manifestation, Domuyo volcano, Neuquén, Argentina Proceeding, Thirty-Fourth Workshop on Geothermal Reservoir Engineering Stanford University, Stanford, California, February 9-11, 20095.

Miranda, F.J., 1996. Caracterización petrográfica y geoquímica del Cerro Domuyo, Pcia. de Neuquén - Argentina. [Licenciatura Thesis]. Buenos Aires. Universidad de Buenos Aires, Buenos Aires, Facultad de Ciencias Exactas y Naturales p. 118.

Miranda, F., Folguera, A., Leal, P., Naranjo, J., Pesce, A., 2006. Upper Pliocene to lower Pleistocene volcanic complexes and Upper Neogene deformation in the south-central Andes $\left(36^{\circ} 30^{\prime \prime}-38^{\circ} \mathrm{S}\right)$. Geol. Soc. Am. Spec. Pap. 407 (specialpapers.gsapubs.org).

Palacio, M., Llambia, E.J., 1978. Las fuentes termales del Volcan Domuyo, Provincia del Neuquen. 7th Argentine Geol. Congress, 9-15 April, 1978, Neuquen (Argentina), 2, pp. 145-159 (In Spanish with English abstract).

Sorey, M.L., 1986. Hot spring monitoring at Lassen Volcanic National Park, California 1983-1985. Proceedings of the 11th Workshop on Geothermal Reservoir Engineering. Stanford University, Stanford, CA, USA, pp. 141-149.

Spagnuolo, M.G., Litvak, V.D., Folguera, A., Bottesi, G., Ramos, V.A., 2012. Neogene magmatic expansion and mountain building processes in the southern Central Andes, 36-37 S, Argentina. J. Geodyn. 53, 81-94.

Suárez, M., Emparan, C., 1995. The stratigraphy, geochronology and paleophysiography of a Miocene fresh-water interarc basin, southern Chile. J. South Am. Earth Sci. 8, 17-31.

Suárez, M., Emparán, C., 1997. Hoja Curacautín. Regiones de la Araucanía y del Bío Bío. Carta Geológica de Chile: Servicio Nacional de Geología y Minería de Chile, Santiago, v. 71 , pp. 105 , scale $1: 250,000,1$ sheet

Taran, Y.A., Peiffer, L., 2009. Hydrology, hydrochemistry and geothermal potential of El Chichón volcano-hydrothermal system, Mexico. Geothermics 38 (4), 370-378. http://dx.doi.org/10.1016/j.geothermics.2009.09.002 (Cited 4 times).

Vakin, E.A., Pilipenko, G.F., 1986. The Mutnovsky geothermal area in Kamchatka. Exploration and Exploitation of Geothermal Resources in Volcanic Areas. Nauka, Moscow, Russia (36-45 pp. (in Russian))

Völker, D., Kutterolf, S., Wehrmann, H., 2011. Comparative mass balance of volcanic edifices at the southern volcanic zone of the Andes between $33^{\circ} \mathrm{S}$ and $46^{\circ} \mathrm{S}$. J. Volcanol. Geotherm. Res. 205, 114-129. 